\title{
AMALAN PENGHAKIMAN DALAM KES WASIAT WAJIBAH KEPADA WARIS BERBEZA AGAMA: KAJIAN KES TERPILIH*
}

\section{The Practice of Judgment of Wajibah Will to the Heirs of Different Religion: A Selected Case Study}

\author{
Zakiul Fuady Muhammad Daud ${ }^{1}$ \\ Raihanah Hj. Azahari
}

\begin{abstract}
The judge is the party with the authority in the law, but sometimes the law that has been enacted does not always fit with the Shariah. Therefore, the purpose of this study is to analyze the decision of the judges in relation to the wajibah wills to the heirs of different religion and the judgment method employed by the judge in determining these decisions in the Islamic perspective. This study is a qualitative descriptive study that combines law in book with law in action by using interview methods to 16 judges in East Java Province, Indonesia and using documentation as a
\end{abstract}

* Kes Nombor 0140/Pdt.P/2012/PA.Sby, Mahkamah Agama Surabaya, Indonesia.

1 Ph.D Candidate, Department Fiqh and Usul, Academy of Islamic Studies, University of Malaya, 50603 Kuala Lumpur, Malaysia; and Lecturer, Faculty of Syariah, STAIN Gajah Putih Takengon, Aceh, Indonesia, zakiul_fuady@yahoo. com

2 Associate Professor, Department Fiqh and Usul, Academy of Islamic Studies, University of Malaya, 50603, Kuala Lumpur, Malaysia, raihan@um.edu.my 
method of data collection. The findings show that the judges gave a wajibah will to the heirs of different religion on the rationale that Islam is the religion of 'rahmatan li al-'älamin' and the method used by the judge is maqāsid al-sharī'ah towards hifz al-nasl and the analogious of zakāh. The decision of the wajibah will to the heirs of the different religions is not in accordance with the Shariah because it violates the rules of Allah SWT in sürah al-Nisā'verse 14. While the method used by the judge does not conform to Shariah also because the practice of Shariah goal should pay attention to five necessities by prioritizing the keeping of religion than the keeping of offspring.

Keywords: wajibah will, heirs of different religion, method of judgment, Shariah

\section{PENDAHULUAN}

Di Indonesia, hakim mahkamah agama adalah antara mereka yang berperanan dalam menetapkan hukum. ${ }^{3}$ Para hakim memutuskan hukum berdasarkan kepada undang-undang yang telah digubal. ${ }^{4}$ Namun demikian, dari sudut realitinya hukum atau undang-undang yang sudah digubal tidak mampu menyelesaikan perkara-perkara yang timbul dalam kalangan masyarakat sehingga merumitkan para hakim dalam menyelesaikannya. ${ }^{5}$

Justeru, parahakimtidakbolehmenolakkes-kes yang didatangkankepadanya dengan alasan bahawa tidak ada undang-undang yang menentukannya. ${ }^{6}$ Oleh itu, hakim dituntut untuk mengkaji dan menentukan hukum agar masyarakat tidak hanya mendapatkan kejelasan hukum, ${ }^{7}$ bahkan berusaha bersungguh-

3 Nurdin Juddah, 'Metode Ijtihad Hakim dalam Penyelesaian Perkara,' Jurnal Diskursus Islam, 1/2 (2013): 254.

4 Sebagaimana pasal 20 AB yang berbunyi: "Hakim mesti mengadili berdasarkan undang-undang".

5 Liza Erwina, 'Penemuan Hukum oleh hakim,' USU Digital Library (2002): 1.

6 Sebagaimana pasal 22 AB dan pasal 14 Undang-undang No. 14 Tahun 1970 yang mewajibkan "Hakim untuk tidak menolak mengadili perkara yang diajukan kepadanya dengan alasan tidak lengkap atau tidak jelas undang-undang yang menentukannya melainkan wajib mengadilinya". Lihat juga Titin Samsudin, 'Peranan Hakim dalam Pengeluaran Hukum,' Jurnal al-Mizan, 10/1 (2014): 98106. Juga Riyanta, 'Metode Penemuan Hukum: Studi Komparatif Hukum Islam dan Hukum Positif,' Jurnal Penelitian Agama, 17/2 (2008): 406-427.

7 Sebagaimana Undang-Undang No. 48 Tahun 2009 Pasal 5 Ayat 1: "Hakim dan hakim konstitusi wajib mengkaji, mengikuti dan memahami nilai-nilai hukum dan rasa keadilan yang hidup dalam masyarakat". 
sungguh untuk menentukan hukum yang memberikan keadilan kepada masyarakat. Namun demikian, apa yang menjadi permasalahan adalah apabila terdapat keputusan penghakiman yang bertentangan dengan ketetapan hukum dalam Islam. Bahkan, penghakiman yang diberikan adalah berbeza dengan undang-undang yang tertulis di dalam Kompilasi Hukum Islam (KHI) sehinggakan isu tersebut sangat penting untuk dikaji dengan lebih lanjut oleh penulis.

Di Yogyakarta, ${ }^{8}$ Mahkamah Agung menetapkan bahawa ahli waris bukan Islam mendapat bahagian daripada harta pusaka melalui wasiat wajibah, ${ }^{9} \mathrm{di}$ mana mengikut ketentuan hukum syarak, ahli waris ini sepatutnya terhalang daripada menerima harta pusaka disebabkan perbezaan agama. ${ }^{10}$ Oleh itu, kajian ini dijalankan bertujuan untuk menganalisis keputusan-keputusan hakim yang berkaitan dengan wasiat wajibah kepada ahli waris yang berbeza agama dan metode penghakiman yang digunakan hakim dalam menetapkan keputusan-keputusan tersebut mengikut perspektif syarak.

\section{KONSEP WASIAT WAJIBAH}

\section{Pengertian Wasiat Wajibah}

Wasiat wajibah merupakan salah satu daripada cabang wasiat dalam Islam. Namun demikian, apabila istilah wasiat dipadankan dengan wajibah, maka

8 Lihat kes dengan nombor $368 \mathrm{~K} / \mathrm{AG} / 1995$ yang bertarikh 16 Julai 1998 dan nombor $51 \mathrm{~K} / \mathrm{AG} / 1999$ bertarikh 29 Februari 1999. Kedua-dua kes ini dibicarakan dan dilanjutkan ke peringkat Mahkamah Agung yang bertempat di Jakarta.

9 Wasiat wajibah bermaksud tindakan penguasa atau hakim sebagai pemerintah negara untuk memutuskan wasiat wajibah bagi orang yang telah meninggal dunia untuk diberikan kepada orang tertentu dalam keadaan tertentu. Lihat Fatchur Rahman, Ilmu Waris (Bandung: Al-Ma'arif, 1994), 63. Lihat juga Abdul Manan, 'Beberapa masalah hukum tentang wasiat dan permasalahannya dalam konteks kewenangan peradilan agama,' Mimbar Hukum Aktualisasi Hukum Islam, 38/1 (1998): 23.

10 Dalam kes ini, pewaris meninggalkan kanak-kanak yang berbeza agama, manakala semasa pewaris sakit, anak yang beragama Nasrani yang menjaganya. Ketika harta warisan dibahagikan, anak yang beragama Nasrani tidak menerima bahagian. Maka ianya mengemukakan tuntutan ke Pengadilan Agama (Mahkamah Agama) tetapi diputuskan tidak menerima bahagian. Pada akhirnya ianya mengemukakan tuntutan dan diputuskan oleh Mahkamah Agung Jakarta untuk menerima bahagian melalui wasiat wajibah sepertimana keputusan nombor $51 \mathrm{~K} / \mathrm{AG} / 1999$ bertarikh 2 Februari 1999. 
ia memberikan makna yang agak berbeza berbanding wasiat biasa. Pada asasnya, wasiat dilakukan secara sukarela (ikhtiyārah) atas kehendak sendiri sehingga seseorang individu mempunyai kebebasan untuk membuat wasiat atau tidak. ${ }^{11}$ Namun demikian, apabila wasiat dipadankan dengan wajibah, maka ia bermakna wasiat tersebut telah diwajibkan. ${ }^{12}$ Secara terminologi, mengikut pendapat sebahagian fuqaha', tabi'in dan imam fiqh, wasiat wajibah adalah wasiat yang wajib diberikan kepada keluarga yang tidak mendapatkan harta pusaka, sepertimana firman Allah SWT dalam al-Quran dalam surah alBaqarah ayat $180 .{ }^{13}$

Mengikut Suparman Usman, wasiat wajibah adalah wasiat yang mana pelaksanaannya tidak bergantung kepada kehendak orang yang meninggal, akan tetapi mestilah dilaksanakan sama ada diucapkan atau pun sebaliknya. Pemberian wasiat wajibah ini bukan berdasarkan kepada bukti, melainkan didasarkan kepada alasan-alasan hukum tertentu. ${ }^{14}$ Selain daripada itu, Ibn Hazm berpendapat bahawa apabila tidak diberikan wasiat untuk saudara mara yang tidak menerima harta pusaka, maka hakim mesti bertindak memberikan sebahagian daripada harta pusaka kepada mereka sebagai wasiat yang wajib untuk mereka. ${ }^{15}$ Definisi yang sama juga terdapat pada ensiklopedia hukum Islam, di mana wasiat wajibah adalah wasiat yang diperuntukkan ahli waris atau saudara mara yang tidak menerima bahagian harta pusaka daripada orang yang meninggal disebabkan terdapat halangan syarak. Contohnya seperti cucucucu yang tidak dapat menerima harta pusaka daripada datuknya disebabkan terhalang oleh bapa saudara mereka. ${ }^{16}$

Manakala Abū Zahrah menyatakan bahawa wasiat wajibah merupakan salah satu hukum taklifi (wajib) yang diikat oleh undang-undang. Dengan demikian, wasiat wajibah merupakan wasiat yang diwajibkan dan dipertanggungkan kepada pewaris untuk dilaksanakan dan ianya adalah berdasarkan kepada undang-undang. ${ }^{17}$ Yahya Harahap pula berpendapat bahawa seseorang individu

11 Moh. Muhibbin \& Abdul Wahid, Hukum Kewarisan Islam; Sebagai Pembaruan Hukum Positif di Indonesia (Jakarta: Sinar Grafika, 2009), 148.

12 Muhammad Hasbi Ash-Shiddieqy, Fiqih Mawaris (Semarang: PT. Pustaka Riski Putra, 1987), 273.

13 Muhammad Hasbi Ash-Shiddieqy, Fiqih Mawaris, 273.

14 Suparman Usman \& Yusuf Somawinata, Fiqh Mawaris: Hukum kewarisan Islam (Jakarta: Gaya Media, 1997), 163.

15 Muhammad Hasbi Ash-Shiddieqy, Fiqih Mawaris, 275.

16 Abdul Aziz Dahlan (ed.), Ensiklopedia Hukum Islam (Jakarta: PT. Ichtiar Baru van Hoeve, 1996), vol. 1, 1930.

17 Muḥammad Abū Zahrah, Sharh Qanun al-Wașiyat (Qāhirah: Maktabah alMașriyah, 1983), 216. 
dibolehkan untuk menerima wasiat mengikut hukum, sama ada pewasiat menyatakannya ataupun tidak. Pandangan ini berasaskan kepada hukum yang mewajibkan untuk berwasiat, sama ada terdapat wasiatnya atau tidak, namun tetap dianggap wujud. ${ }^{18}$ Abdul Manan juga menyampaikan pendapat yang sama bahawa wasiat wajibah merupakan tindakan yang dilakukan oleh hakim sebagai pemerintah negara untuk memutuskan wajibnya wasiat bagi orang yang meninggal dunia kepada orang tertentu dalam keadaan tertentu. ${ }^{19}$ Daripada definisi yang diberikan oleh pakar, maka dapat disimpulkan bahawa wasiat wajibah mengandungi dua unsur, iaitu:

a) Tidak memerlukan kerelaan mahupun pernyataan daripada si mati untuk memberikan wasiat kepada saudara mara. Dengan demikian, walaupun mereka yang meninggal tidak berwasiat, namun tetap dianggap sebagai wasiat.

b) Hakim bertindak sebagai pewasiat untuk membahagikan maksimum satu pertiga harta si mati untuk diberikan saudara mara yang terhalang untuk mendapatkan harta pusaka.

\section{Dasar Hukum Wasiat Wajibah}

Istilah wasiat wajibah merupakan istilah yang berkembang pada abad ke-20 dan istilah ini tidak dijelaskan dalam kitab-kitab fiqh klasik. ${ }^{20}$ Oleh itu, dalam menentukan ada atau tidaknya wasiat wajibah dalam Islam, adalah merupakan sesuatu yang bersifat kontroversi dan memerlukan ijtihad daripada ulama. Oleh yang demikian, terdapat perbezaan pendapat tentang permasalahan ini.

Pada hakikatnya, dasar hukum wasiat wajibah sepertimana dasar hukum wasiat itu sendiri di dalam al-Quran:

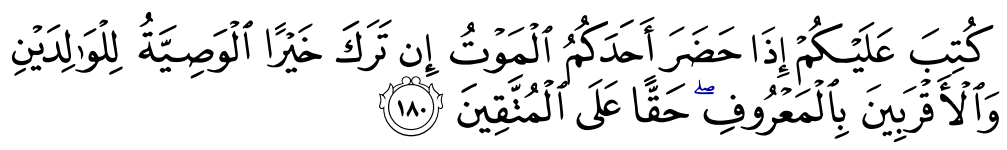

"Diwajibkan atas kamu, apabila seorang di antara kamu kedatangan (tanda-tanda) maut, jika ia meninggalkan harta yang

18 M.Yahya Harahap, Informasi Materi KHI; Mempositifkan Abstraksi Hukum Islam (Jakarta: Yayasan al-Hikmah, 1993/1994), 191-192.

19 Abdul Manan, 'Beberapa masalah hukum tentang wasiat dan permasalahannya dalam konteks kewenangan peradilan agama,' 23.

20 Khairani, Wasiat Wajibah dalam Pemikiran Hukum Ibn Hazm (Banda Aceh: Searfiqh, 2012), 12. 
banyak, berwasiat untuk ibu bapa dan karib kerabatnya secara
ma'ruf(ini adalah) kewajipan atas orang-orang yang bertaqwa."

(Surah al-Baqarah, 2: 180)

Namun demikian, dalam mentafsirkan ayat berkenaan wasiat di atas, ulama berbeza pendapat tentang amalan wasiat wajibah. Sesetengah ulama bersetuju atau mewajibkan wasiat wajibah, tetapi ada juga yang tidak bersetuju atau menganggap bahawa wasiat wajibah hukumnya sunnah, bahkan tidak boleh diamalkan. Golongan yang bersetuju dengan wasiat wajibah adalah Abī 'Abd Allāh Muḥammad bin 'Umar al-Razi, Sayyid Quṭb, Muhammad 'Abduh, Said bin Jabir, Rabi' bin Ānas, Qatādah, Muqatil bin Hayyan, Ibn 'Abbās, dan al-Hasan. ${ }^{21}$ Ibn Hazm turut bersetuju dengan amalan wasiat wajibah ini. Alasan yang digunapakai adalah; pertama, kewajipan yang terdapat pada ayat 180 surah al-Baqarah hanya diperuntukkan kepada ibu bapa (wālidayn) dan saudara mara (aqrabin) yang terhalang atau yang tidak menjadi ahli waris. ${ }^{22} \mathrm{Hal}$ ini ditegaskan oleh Ibn Hazm yang menyatakan bahawa perintah berwasiat dalam ayat wasiat masih tetap berlaku dan hukumnya masih wajib. Perintah yang dibatalkan hanya untuk keluarga yang telah menjadi ahli waris. Sehinggalah apabila seseorang Muslim meninggal dan tidak berwasiat sebelum peninggalannya, maka ahli waris wajib mengeluarkan sebahagian daripada harta pusakanya. ${ }^{23}$ Lebih daripada itu, apabila kewajipan ini tidak dipenuhi, maka mahkamah atau penguasa (ulul amri) berkewajipan untuk mengeluarkan wasiat demi memenuhi kewajipan wasiat ini. ${ }^{24}$

21 Suparman Usman \& Yusuf Somawinata, Fiqh Mawaris: Hukum kewarisan Islam, 164.

22 Al-Jașaș, Aḥkām al-Qur'ān (Bayrūt: Dār al-Kitāb al-'Arab̄i, t.t.), vol. 2. 164. Muhammad bin Ahmad Al-Qurthuby, al-Jami' li Ahkām al-Qur'ān, vol. 3 (Qāhirah: Dār al-Hadith, 1999), 262-263. Rashid Ridha, Tafsir al-Qur'ān alHakim, vol. 2 (Qāhirah: Maktabah al- Qāhirah, t.t.), 361.

23 Ibn Hazm juga menyatakan bahawa "diwajibkan bagi setiap Muslim untuk berwasiat kepada saudara mara yang tidak menerima harta pusaka sama ada kerana perhambaan, perbezaan agama, terhalang mahupun disebabkan bukan ahli waris. Hendaknya ianya berwasiat sekehendaknya, tidak ada had. Sekiranya ianya meninggal dan tidak berwasiat, maka ahli waris mesti memberikan kepada mereka yang dianggap patut". Beliau juga menambahkan bahawa jika ibu bapanya atau salah daripada keduanya beragama lain, atau menjadi hamba sahaya,wajib pula baginya untuk memberikan wasiat kepada kedua-duanya atau salah satunya meskipun ianya tidak berwasiat, maka tetap mesti dikeluarkan wasiatnya selepas itu baru boleh berwasiat untuk yang lain. Ibn Hazm, al-Muhalla, vol. 9 (Bayrūt: Dār al-Fikr, 1983), 313-314.

24 Badran Abū al-Ainani, Aḥkām al-Wașaya wa al-Awqaf (Iskandariyah: Muassasah Shabab al-Jami'ah, 1982), 6. 
Namun demikian, jumhur ulama bersepakat bahawa hukum berwasiat kepada saudara mara yang tidak menerima harta pusaka adalah sunnah. Adapun hujah yang digunapakai oleh jumhur ulama adalah; pertama, lafaz kutiba dalam ayat 180 surah al-Baqarah sudah dinasakhkan oleh ayat-ayat pusaka (mawārith) yang menerangkan bahagian ahli waris masing-masing seperti ibu bapa, dan saudara mara dengan ketentuan yang sudah pasti. ${ }^{25} \mathrm{Kedua}$, kewajipan dalam ayat wasiat ini juga sudah dinasakh oleh hadis Rasulullah SAW sebagaimana berikut: ${ }^{26}$

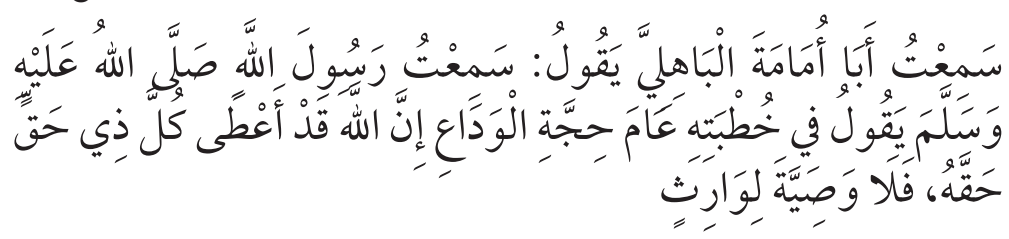

"Dari Abū Umamah RA berkata: saya mendengar Rasulullah SAW bersabda dalam salah satu khutbah beliau pada tahun haji wada' bahawa Allah SWT telah memberikan hak kepada siapa yang berhak. Oleh itu, tidak ada hak mendapat wasiat bagi para ahli waris." 27

Ketiga, berdasarkan sejarah Islam, Rasulullah SAW dan kebanyakan sahabat tidak mengamalkan pemberian wasiat untuk saudara mara. ${ }^{28} \mathrm{Keempat}$, jumhur ulama mengaitkan antara istilah kutiba dengan khayran. Oleh yang demikian, mereka cenderung berpendapat bahawa kewajipan berwasiat hanya diperuntukkan bagi orang-orang kaya atau mereka yang mencapai had harta. ${ }^{29}$ Dengan demikian, jumhur tidak lagi memaknakan perkataan kutiba dengan

\footnotetext{
25 Khairani, Wasiat Wajibah dalam Pemikiran Hukum Ibn Hazm, 2.

26 Khairani, Wasiat Wajibah dalam Pemikiran Hukum Ibn Hazm, 3.

27 Hadis riwayat Ibn Majah dalam kitab "wasāya $\bar{a}$ " bab "lā wasiyyata liwārith" (905/2) no. 2713, Al-Imam Al-Hāfiz Ab̄̄ 'Abd Allāh Muḥammad bin Yāzid al-Rabi‘ Ibn Mājah, Sunan Ibn Mājah (Riyāḍ: Dār al-Salām, 1999). Tirmidhī dalam kitab "alzakāh", bab "fi nafaqah al-mar'ati min baiti zaujihä" (48/3) no. 670, Muhammad bin Isa bin Surah al-Tirmidhī, al-Jam̄̄' al-Șaḥ̄h Sunan al-Tirmidhī (Qāhirah: Muṣtafa al-Bābi al-Halabi, 1977). Abū Dāwud dalam kitab “al-Wāsāyā", bab " $m \bar{a}$ ja'a fi al-wasāyā li al-wārith" (114/3) no. 2870, Imam Abū Dāwud al-Sijistān̄̄, Sunan Abū Dāwud (Bayrūt: Maktab al-Dirāsat wa al-buhūth fi Dār al-Fikr, t.t).

28 Fatchurrahman, Ilmu Waris, 54. Al-Yasa Abu Bakar, 'Ahli Waris Sepertalian Darah: Kajian Perbandingan Terhadap Penalaran Hazairin dan Penalaran Fikih Madzhab,' (Disertasi Sarjana, Fakultas Pasca Sarjana IAIN Sunan Kalijaga, Yogyakarta, 1989), 382.

29 Aḥmad Mustafa al-Maraghi, Tafsir al-Maraghi, vol. 4 (Qāhirah: al-Bab al-Halabi, 1974), 80. Rasyid Ridha, Tafsir al-Qur'ān, 132.
} 
wajib, bahkan apabila ada seseorang Muslim yang berwasiat untuk ahli waris, maka secara hukum dianggap tidak sah atau terbatal. ${ }^{30}$

\section{METODOLOGI KAJIAN}

Kajian ini menggunakan pendekatan gabungan antara kajian undangundang normatif atau normatif legal research (law in book) dan kajian undang-undang empirikal (law in action) terhadap peraturan wasiat wajibah dan amalannya melalui keputusan-keputusan mahkamah oleh Mahkamah Agung dan Mahkamah Agama di Jawa Timur. Reka bentuk kajian ini adalah kajian kualitatif yang memberi tumpuan kepada fenomena yang sudah dan sedang berlaku. Justeru, dengan menggunakan reka bentuk ini, penulis dapat memahami secara mendalam tentang fenomena yang menjadi kajian penulis. ${ }^{31}$

Dalam kajian ini, penulis menggunakan kaedah persampelan bertujuan (purposive sampling); iaitu kaedah persampelan yang memilih sumber data dengan pertimbangan tertentu. ${ }^{32}$ Responden dalam kajian ini adalah seorang Hakim Agung, empat orang Hakim Tinggi Agama daripada Mahkamah Tinggi Agama (Mahkamah Agama Tinggi) dan 11 orang Hakim tahap I daripada Mahkamah Agama atau Mahkamah Rendah di sesetengah daerah di wilayah Jawa Timur, Indonesia. Hakim-hakim yang dipilih tidak hanya tertumpu kepada Mahkamah Agama sahaja, melainkan daripada beberapa mahkamah yang bertujuan untuk mendapatkan pandangan dan pengalaman yang pelbagai berkaitan dengan keputusan wasiat wajibah.

Kaedah pengumpulan data dalam kajian ini terdiri daripada dua kaedah, iaitu temu bual dan dokumentasi. Temu bual (interview), iaitu perjumpaan antara penulis dengan responden untuk bertukar maklumat melalui soalan-soalan yang diberikan sehingga dapat dibina makna yang berkenaan dengan topik tertentu. Kaedah temu bual ini boleh digunakan penulis untuk mendapatkan maklumat awal sebelum diadakan kajian dan juga boleh digunakan untuk mendapatkan maklumat secara mendalam. ${ }^{33}$

Dalam kajian ini, kaedah temu bual yang penulis gunakan adalah kaedah temu bual separa berstruktur (semi structure interview) di mana penulis berhasrat untuk mendapatkan maklumat yang lebih mendalam dan terbuka.

30 Khairani, Wasiat Wajibah dalam Pemikiran Hukum Ibn Hazm, 4.

31 Chua Yan Piaw, Kaedah dan Statistik Pengkajian: Asas Statistik Pengkajian Buku 2 (Malaysia: McGraw-Hill, 2006), 47.

32 Chua Yan Piaw, Kaedah dan Statistik Pengkajian: Asas Statistik Pengkajian Buku 2, 301 .

33 Sugiyono, Metode Penelitian Kombinasi (Mixed Methods) (Bandung: Alfabeta, 2014), 316. 
Di sini, penulis melengkapkan beberapa soalan yang berkaitan dengan topik kajian penulis. Dalam masa yang sama, penulis juga memberikan soalan tambahan semasa proses temu bual dijalankan sekiranya diperlukan. Dalam kajian ini, penulis mengadakan temu bual bersama 16 orang hakim yang terdiri daripada 11 orang Hakim tahap I, empat orang Hakim Tinggi dan seorang Hakim Agung.

Manakala dokumentasi adalah kaedah pengumpulan data yang menggunakan dokumen sebagai data. Dokumen merupakan catatan kejadian lepas sama ada dalam bentuk tulisan, gambar mahupun karya-karya seseorang. ${ }^{34}$ Dalam kajian ini, dokumen yang dikumpulkan adalah berupa perundangan, iaitu hasil keputusan mahkamah yang berkaitan dengan wasiat wajibah kepada ahli waris yang berbeza agama.

Dalam kajian ini, penulis menganalisis data kualitatif deskriptif melalui kaedah deduktif (luar kepada dalam/umum kepada khusus) dan induktif (dalam kepada luar/khusus kepada umum) dengan cara mendedahkan data yang diperoleh yang berdasarkan penelitian kepada undang-undang, nas-nas dan teori-teori undang-undang yang ada.

\section{METODE PENGHAKIMAN DALAM PEMBERIAN WASIAT WAJIBAH KEPADA AHLI WARIS BERBEZA AGAMA: KAJIAN KES TERPILIH}

Kes yang diambil dalam kajian ini merupakan kes yang kerap berlaku di mahkamah agama dan keputusan hakim yang terdapat dalam kes ini juga sama dengan keputusan yang diberikan kepada kes-kes lain yang serupa. Oleh itu, pengkaji memilih kes ini untuk dijadikan sebagai bahan kajian dengan tujuan dapat mewakili kes-kes lain yang serupa yang berkaitan dengan wasiat wajibah. Dalam kes terpilih ini (Kes Nombor 0140/Pdt.P/2012/PA.Sby), seorang lelaki meninggal dunia dan meninggalkan ahli waris yang terdiri daripada seorang isteri, dan lima orang anak kandung. Lelaki yang meninggal dunia beragama Islam begitu juga isteri yang ditinggalkan juga beragama Islam. Sementara anak yang pertama pada awalnya beragama Islam, kemudian bertukar kepada agama Kristian. Manakala anak yang kedua, ketiga, keempat dan kelima kekal beragama Islam. Dalam kes ini, pihak yang memohon ke mahkamah adalah isteri, anak kedua, ketiga, keempat dan kelima. Mereka meminta kepada hakim untuk menetapkan mereka menjadi ahli waris bapanya yang meninggal. Manakala bagi anak pertama yang beragama Kristian, mereka meminta diberikan wasiat wajibah disebabkan perbezaan agama walaupun bapa mereka tidak berwasiat sebelum ianya meninggal dunia.

34 Sugiyono, Metode Penelitian Kombinasi (Mixed Methods), 326. 
Berdasarkan permohonan para plaintif di atas, hakim memberikan keputusan dengan memberikan wasiat wajibah kepada anak kandung yang sudah murtad (beragama Kristian), bukan dalam kapasiti sebagai ahli waris. Oleh yang demikian, anak kandung ini menerima wasiat serta merta walaupun tidak diwasiatkan sebelumnya.

Landasan hukum yang dijadikan rujukan hakim dalam menetapkan keputusan ini adalah sepertimana berikut:

a) Perundangan Putusan Mahkamah Agung RI Nombor: 368 K/AG/1995 bertarikh 16 Julai 1998.

b) Perundangan Putusan Mahkamah Agung RI Nombor: 51K/AG/1999 bertarikh 29 September 1999 yang salah satu keputusannya adalah anak kandung yang bukan Muslim tidak menjadi ahli waris namun ianya berhak menerima bahagian daripada harta pusaka melalui wasiat wajibah.

Dalam menyelesaikan kes ini, mengikut Hakim Tinggi Muhammad Rum Nessa, hakim menggunakan metode penghakiman berdasarkan maqāșid alsharī'ah sebagai usaha menjaga keturunan (hifz al-nasl) disebabkan penjagaan terhadap keturunan merupakan sesuatu yang penting dalam Islam. ${ }^{35}$ Beliau berpandangan bahawa keputusan tersebut adalah sebagai usaha untuk menjaga keturunan daripada kemiskinan hingga akhirnya hakim mewajibkan pewaris untuk berwasiat. Pandangan ini disokong oleh Hakim Tinggi Muzni Ilyas yang menyatakan bahawa sememangnya golongan bukan Muslim itu bukan ahli waris. Walau bagaimanapun, ia tetap sebagai anak kandung. Bahkan anak angkat yang tidak mempunyai hubungan darah sekalipun turut diberikan harta pusaka melalui wasiat wajibah, apatah lagi untuk mereka yang sedarah. Oleh kerana terdapat perbezaan agama, maka ianya diberikan secara wasiat wajibah sahaja, bukan sebagai pusaka. Pandangan ini dikuatkan oleh hakim peringkat I lainnya seperti hakim Zamroni, hakim Mulyani, hakim Tamali dan hakim Eni Rianing Taro. ${ }^{36}$ Manakala menurut Hakim Agung Amran Suadi, keputusan perundangan yang dijadikan panduan oleh hakim dalam memutuskan perkara

35 Muhammad Rum Nessa (Hakim Tinggi, Mahkamah Tinggi Agama Jawa Timur), dalam temu bual beliau dengan penulis pada 6 Mac 2017.

36 Muzni Ilyas (Hakim Tinggi, Agama Mahkamah Tinggi Jawa Timur), dalam temu bual beliau dengan penulis pada 3 Mac 2017; Zamroni (Hakim Agama, Mahkamah Agama Sumenep), dalam temu bual beliau dengan penulis pada 23 Januari 2017; Mulyani (Hakim Agama, Mahkamah Agama Mojokerto), dalam temu bual beliau dengan penulis pada 3 Mac 2017; Tamali (Hakim Agama, Mahkamah Agama Mojokerto), dalam temu bual beliau dengan penulis pada 3 Mac 2017; Eni Rianing Taro (Hakim Agama, Mahkamah Agama Mojokerto), dalam temu bual beliau dengan penulis pada 3 Mac 2017. 
tersebut menampakkan keberanian dan kreativitinya dalam membina hukum Islam yang berbeza dengan undang-undang normatif. Hal ini disebabkan undang-undang normatif hanya menentukan wasiat wajibah kepada anak angkat sahaja. ${ }^{37}$

Selain daripada itu, hakim tersebut menggunakan metode mașlaḥah almursalah. Hal ini jelas tergambar daripada keputusan penghakiman yang menetapkan wasiat wajibah bagi anak yang beragama Kristian bagi menjaga keharmonian di antara mereka. Lebih-lebih lagi dalam kes ini, anak kandung yang beragama Islam meminta saudaranya yang Kristian untuk diberikan wasiat wajibah. Sekiranya hakim tidak memberikan, nescaya akan merenggangkan hubungan yang sudah terbina hingga Islam yang bersifat rahmatan lil 'alamin tidak dapat diwujudkan.

Tambahan pula, ahli waris yang beragama Kristian merupakan anak kandung pewaris. Alangkah rugi seandainya anak kandung tidak dapat menerima apaapa bahagian daripada harta pewaris, sedangkan mereka menyatakan bahawa hubungan antara anak dan ibu bapa tersebut tetap harmoni meskipun berbeza agama. Pandangan tersebut sepertimana yang diberikan oleh Hakim Tinggi Muhammad Rum Nessa, Hakim Muzni Ilyas, dan Hakim Eni Rianing Taro. ${ }^{38}$ Tambahan pula, menurut Hakim Tinggi Agus Dimyati, keputusan tersebut juga dikuatkan dengan al-Quran untuk berwasiat kepada orang yang tidak menerima harta pusaka. Seandainya perkara tersebut menjadi objek khilaf, maka إذا حكم الحاكم في مسائل الخلاف يرفغ الخلاف. (maksudnya: apabila hakim berhukum pada masalah khilaf, maka akan mengangkat khilaf tersebut). ${ }^{39}$ Oleh yang demikian, keputusan penghakiman adalah menjadi penentu kepada hukum. Seandainya bahagian harta tidak diberikan kepada anak yang bukan Muslim, maka sama seperti membiarkan kehidupan mereka terabai walaupun keluarga sendiri. ${ }^{40}$

Seterusnya, metode penghakiman lain yang diguna pakai oleh hakim dalam pemberian wasiat wajibah dalam kes ini adalah berdasarkan kaedah qiyās. Di sini, hakim mengqiyāskan pemberian harta kepada bukan Muslim melalui

37 Amran Suadi (Hakim Agung Mahkamah Agung R.I), dalam temu bual beliau dengan penulis pada 7 Mac 2017.

38 Muhammad Rum Nessa (Hakim Tinggi, Mahkamah Tinggi Agama Jawa Timur), dalam temu bual beliau dengan penulis pada 6 Mac 2017; Muzni Ilyas (Hakim Tinggi, Agama Mahkamah Tinggi Jawa Timur), dalam temu bual beliau dengan penulis pada 3 Mac 2017; Eni Rianing Taro (Hakim Agama, Mahkamah Agama Mojokerto), dalam temu bual beliau dengan penulis pada 3 Mac 2017.

39 Kaedah usul fiqh.

40 Agus Dimyati (Hakim Tinggi, Mahkamah Tinggi Agama Jawa Timur), dalam temu bual beliau dengan penulis pada 3 Mac 2017. 
wasiat wajibah sebagaimana zakat diberikan kepada bukan Muslim dalam rangka qulūb ta'līf dengan harapan agar keluarga yang bukan Muslim pun akan lembut hatinya untuk menerima Islam. ${ }^{41}$ 'Illah yang terkandung dalam pemberian pusaka kepada ahli waris Muslim adalah demi kelangsungan hidup, menjaga keturunan dan sebagainya. ${ }^{42}$ 'Illah yang sama pula didapati pada pemberian wasiat wajibah bagi bukan Muslim dan jika berubah 'illah, maka hukum turut berubah. ${ }^{43}$

Metode lain yang digunakan oleh para hakim menurut Hakim Tinggi Rum Nessa dan Hakim Zamroni adalah tafsiran sistematik, di mana hakim menggabungkan pentafsiran perundangan dalam KHI dengan perundangan lain (undang-undang sivil) sehingga boleh menentukan hukum yang memberikan keadilan dan kebenaran terhadap hukum itu sendiri. Ini disebabkan di dalam sistem perwarisan sivil, isu berlainan agama bukanlah penghalang seseorang untuk menerima harta pusaka. Namun agar tidak bercanggah dengan hukum Islam, maka hakim mencari usaha lain dengan bersandarkan undang-undang untuk memberikan bahagian bagi anak yang beragama Kristian. ${ }^{44}$

Manakala menurut Hakim Tinggi Hasan Bisri, dalam kes ini hakim menggunakan metode tafsiran teleologi, di mana kedudukan hakim yang menetapkan makna dalam undang-undang atas dasar kemasyarakatan. Akhirnya para hakim memutuskan perkara sesuai dengan tujuan yang ingin dicapai dalam undang-undang, meskipun tidak menggunakan undangundang sebagai sandaran penghakiman kerana dianggap tidak relevan bahkan sudah usang. Oleh yang demikian, hakim menetapkan sesuatu yang berbeza dengan undang-undang dalam KHI dan mengambil perundangan sebagai langkah yang lebih baik dalam menuju keadilan. ${ }^{45}$ Pandangan ini dikuatkan oleh Hakim Tinggi Muzni Ilyas yang mengatakan bahawa amat sukar untuk menggabungkan tujuan hukum dalam waktu yang sama. Namun demikian,

41 Ahmad Husni (Hakim, Mahkamah Agama Jombang), dalam temu bual beliau dengan penulis pada 2 Mac 2017; Suyatman (Hakim, Mahkamah Agama Jombang), dalam temu bual beliau dengan penulis pada 2 Mac 2017.

42 Muzni Ilyas (Hakim Tinggi, Agama Mahkamah Tinggi Jawa Timur), dalam temu bual beliau dengan penulis pada 3 Mac 2017.

43 Kaedah fiqh, "apabila 'illah berubah, maka hukum pun ikut berubah."

44 Muhammad Rum Nessa (Hakim Tinggi, Mahkamah Tinggi Agama Jawa Timur), dalam temu bual beliau dengan penulis pada 6 Mac 2017; Zamroni (Hakim Agama, Mahkamah Agama Sumenep), dalam temu bual beliau dengan penulis pada 23 Januari 2017.

45 Hasan Bisri (Hakim Tinggi, Mahkamah Tinggi Agama Jawa Timur), dalam temu bual beliau dengan penulis pada 3 Mac 2017. 
apabila hukum bertentangan dengan prinsip keadilan, kemanfaatan dan kepastian, maka yang diutamakan adalah keadilan. ${ }^{46}$

Metode tafsiran sejarah turut digunakan dalam penghakiman bagi kes-kes tertentu. Penggunaan metode ini dilihat melalui penyelidikan terhadap sejarah undang-undang, di mana KHI memberikan hak perwarisan melalui wasiat wajibah kepada yang bukan waris, dengan tujuan keadilan dan kemaslahatan bagi masyarakat. Hal ini juga berlaku dalam pemberian wasiat wajibah bagi bukan Muslim. Tambahan pula, hubungan antara Muslim dengan bukan Muslim pada zaman dahulu berbeza keadaannya dengan zaman kini. ${ }^{47}$

Berbeza pula dengan pendapat Hakim Tinggi Agus Dimyati yang menyatakan bahawa dalam kes ini, metode tafsiran digunakan dengan lebih meluas. Hakim menggunakan metode ini ketika mentafsirkan undang-undang KHI yang menentukan wasiat wajibah hanya terhad kepada anak angkat atau ibu bapa angkat sahaja. Seterusnya tafsiran tersebut diluaskan kepada wasiat wajibah bagi bukan Muslim. Di sini hakim memperluaskan makna bagi istilah yang terdapat dalam undang-undang kepada peristiwa yang tidak diatur, namun mencerminkan nilai-nilai keadilan. Anak angkat atau ibu bapa angkat hanya diberikan wasiat wajibah disebabkan kedudukan mereka bukan sebagai ahli waris. Demikian juga bukan Muslim yang tidak boleh menjadi ahli waris, maka diberikan wasiat wajibah. ${ }^{48}$

Tambahan pula, hakim juga menggunakan metode argumentum a per analogium. Metode ini jelas kelihatan apabila hakim menyamakan aturan perundangan kepada perkara yang serupa atau sejenis, iaitu bukan Muslim yang seharusnya terhalang daripada menerima harta pusaka, akan tetapi boleh menerimanya melalui wasiat wajibah. Di sini hakim menganalogikannya dengan wasiat wajibah bagi anak angkat. ${ }^{49}$

\section{ANALISIS KEPUTUSAN HAKIM DAN METODE PENGHAKIMAN YANG DIGUNAKAN DALAM PERSPEKTIF SYARAK}

Ketika hakim memutuskan pemberian bahagian kepada anak yang berbeza agama melalui wasiat wajibah, tindakan ini pada asalnya bertentangan

46 Muzni Ilyas (Hakim Tinggi, Agama Mahkamah Tinggi Jawa Timur), dalam temu bual beliau dengan penulis pada 3 Mac 2017.

47 Muzni Ilyas (Hakim Tinggi, Agama Mahkamah Tinggi Jawa Timur), dalam temu bual beliau dengan penulis pada 3 Mac 2017.

48 Agus Dimyati (Hakim Tinggi, Mahkamah Tinggi Agama Jawa Timur), dalam temu bual beliau dengan penulis pada 3 Mac 2017.

49 Agus Dimyati (Hakim Tinggi, Mahkamah Tinggi Agama Jawa Timur), dalam temu bual beliau dengan penulis pada 3 Mac 2017. 
dengan hadis Rasulullah SAW yang diriwayatkan oleh Bukhari dan Muslim sebagaimana berikut:

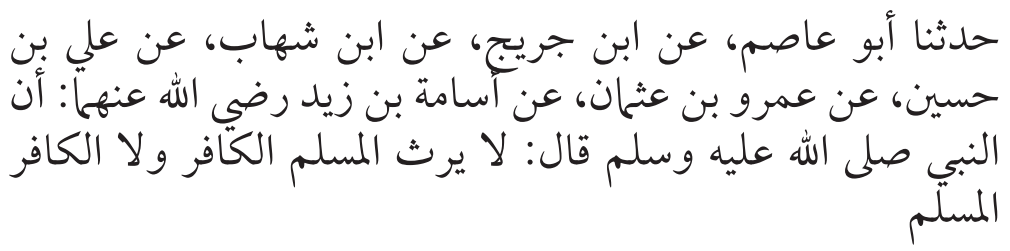

"Abu Asim telah menceritakan daripada Ibn Juraij, daripada Ibn Shihāb, daripada 'Ali Ibn Husayn, daripada Amr Ibn Uthmān daripada Usāmah Ibn Zayd RA: Sesungguhnya Rasulullah bersabda: "Seorang Muslim tidak boleh mendapatkan waris daripada seorang kafir. Dan seorang kafir tidak boleh mendapatkan waris daripada seorang Muslim." 50

Hadis tersebut merupakan ketetapan Allah SWT yang wajib dipatuhi oleh umatNya, sehinggakan apabila seseorang Muslim tidak patuh dengan aturan tersebut, maka ianya akan menerima azab yang pedih sebagaimana dalam firman Allah SWT dalam al-Quran:

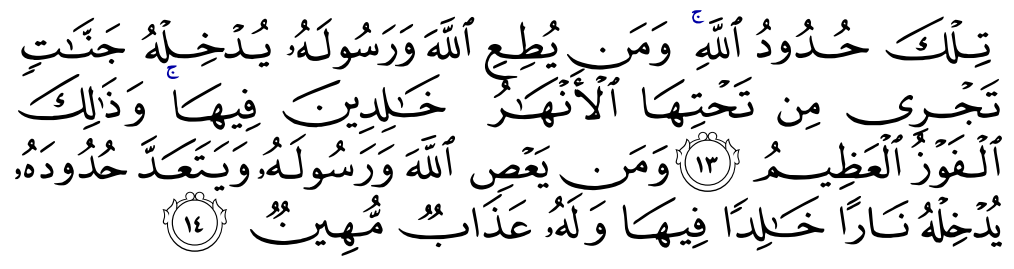

"(Hukum-hukum tersebut) itu adalah ketentuan-ketentuan dari Allah. Sesiapa taat kepada Allah dan Rasul-Nya, nescaya Allah memasukkannya ke dalam syurga yang mengalir di dalamnya sungai-sungai, sedang mereka kekal di dalamnya; dan itulah kemenangan yang besar (13). Dan sesiapa yang menderhakai Allah dan rasul-Nya dan melanggar ketentuan-ketentuan-Nya, nescaya Allah memasukkannya ke dalam api neraka sedang ia kekal di dalamnya; dan baginya seksa yang menghinakan (14)..."

(Surah al-Nisā', 4: 13-14)

50 Diriwayatkan oleh Imam al-Bukhari, kitab "al-farā 'id", bab "lā yarithu al muslimu al kāfira wa lā al kāfiru al muslima" (158/6) no. 6764, Imam Bukhārī, Ṣahīh al-Bukhārī (Qāhirah: Dār al-Ḥad̄ith, 1984). Imam Muslim, kitab "al-fara'idh" (1233/3) no. 1614, Imam Muslim, Șaḥ̄h Muslim (Qāhirah: Dār al-Ḥadīth, 1988). 
Anak yang berbeza agama dalam kes ini adalah termasuk daripada ahli waris pewaris apabila dilihat melalui hubungan darah. Namun demikian, disebabkan ianya murtad daripada Islam, maka ianya tergolong ke dalam golongan terhalang $($ mamn $\bar{u}$ ') daripada menerima harta pusaka tersebut. Dalam hal wasiat kepada anak yang beragama Kristian pun masih menjadi perdebatan dalam kalangan fuqaha. Apatah lagi apabila pewaris tidak berwasiat dan hakim memutuskan untuk memberikan wasiat dengan alasan keadilan antara anak pewaris, sedangkan sepatutnya mereka terhalang daripada menerimanya. Hal ini sudah menjadi kesepakatan jumhur ulama bahawa perbezaan agama merupakan salah satu perkara yang menghalang seseorang daripada menerima harta pusaka. ${ }^{51}$

Sememangnya keadilan merupakan salah satu asas dalam hukum pusaka Islam dan hal tersebut merupakan instrumen penting yang perlu dilakukan oleh setiap Muslim untuk meningkatkan ketaqwaaan kepada Allah SWT. Sepertimana dalam firman Allah SWT dalam al-Quran:

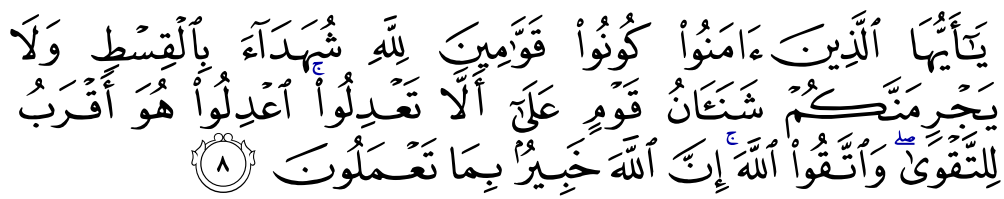

"Wahai orang-orang yang beriman, jadilah kamu penegak keadilan kerana Allah (ketika) menjadi saksi dengan adil. Dan janganlah kebencianmu terhadap sesuatu kaum membawa kamu untuk berbuat tidak adil. Berbuat adillah kerana adil itu lebih dekat kepada taqwa. Dan bertaqwalah kepada Allah, sungguh Allah Maha Teliti apa-apa yang kamu kerjakan."

(Surah al-Mā'idah, 5: 8)

Namun demikian, apa yang dimaksudkan dengan keadilan di sini adalah keadilan yang seimbang antara ahli waris lelaki dan perempuan. Keduaduanya menerima harta pusaka walaupun berbeza kadar bahagiannya. Dengan demikian, asas keadilan dalam hukum pusaka Islam bukanlah keadilan merata yang tidak melihat kepada akidah anaknya.

51 Jasim Zahid, Asbāb al-Irth wa Mawāni 'uhu fì al-Fiqh al-Islāmī (Mekkah: Jami'ah Umm al-Qura, 1982), 37; Yūsuf Mūsā, al-Tirkah wa al-Mīrath fì al-Islām; Baḥth Muqāran (Qāhirah: Dār al-Ma‘rifah, 1967), 169; M. Ali Ash-Shabuni, Pembagian Waris Menurut Islam (Jakarta: Gema Insani, 1995), 41; M. Muhyidin Abd. Hamid, Panduan Waris Empat Madzhab, terj. Wahyudi Abdurrahim (Jakarta: Pustaka AlKautsar, 2009), 47. 
Selain daripada itu, apabila dilihat kepada kisah-kisah dalam al-Quran, jika dalam sesebuah keluarga terdapat ahli keluarga yang berbeza kepercayaannya dengan apa yang dibawa oleh seseorang bapa, maka mereka bukan dianggap sebagai anaknya walaupun daripada darah daging yang sama. Sepertimana dalam kisah nabi Nuh dengan anak ${ }^{52}$ dan isterinya ${ }^{53}$ dan sebagainya.

Walau bagaimanapun, pelaksanaan keadilan dalam Islam perlu melihat kepada tujuan penetapan syarak, iaitu dengan mempertimbangkan darūriyyah al-khamsah yang mana salah satunya adalah menjaga agama (hifz al-al-dìn. Perkara ini berkait rapat dengan firman Allah SWT di dalam al-Quran:

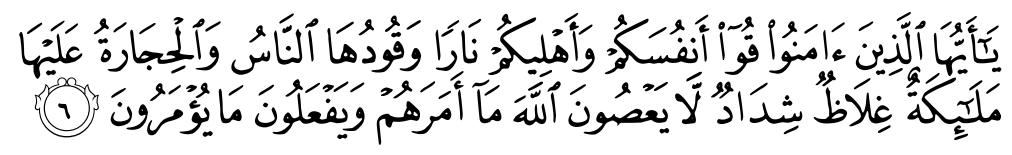

"Wahai orang-orang yang beriman, peliharalah diri kamu dan keluarga kamu dari neraka yang bahan-bahan bakarnya manusia dan batu (berhala); neraka itu dijaga dan dikawal oleh malaikat-malaikat yang keras kasa (layanannya); mereka tidak menderhaka kepada Allah dalam segala yang diperintahkanNya kepada mereka, dan mereka pula tetap melakukan segala yang diperintahkan."

(Surah al-Taḥrīm, 66: 6)

Oleh yang demikian, menjadi tanggungjawab ketua keluarga untuk menjaga ahli keluarganya agar mengelakkan daripada perbuatan murtad dengan cara menjaga akidah mereka. Dengan demikian, menjaga agama merupakan asas teras yang perlu menjadi tumpuan utama dalam mengambil sesuatu keputusan.

Selain daripada itu, salah satu asas dalam hukum pusaka Islam adalah asas ijbari, iaitu wujudnya paksaan terhadap peralihan harta, sesiapa yang berhak

52 Ini sebagaimana dalam Surah Hud ayat 45-46 yang maksudnya: "Dan Nuh berseru kepada Tuhannya sambil berkata: "Ya Tuhanku, Sesungguhnya anakku termasuk keluargaku, dan Sesungguhnya janji Engkau Itulah yang benar. dan Engkau adalah hakim yang seadil-adilnya" (45). Allah berfirman: "Hai Nuh, Sesungguhnya dia bukanlah termasuk keluargamu (yang dijanjikan akan diselamatkan), Sesungguhnya (perbuatan)nya itu perbuatan yang tidak baik. Sebab itu janganlah kamu memohon kepada-Ku sesuatu yang kamu tidak mengetahui (hakikat)nya. Sesungguhnya Aku memperingatkan kepadamu supaya kamu jangan termasuk orang-orang yang tidak berpengetahuan" (46).

53 Sebagaimana dalam Surah al-A'raf ayat 83 yang bermaksud: "kemudian Kami selamatkan dia dan pengikutnya kecuali isterinya. Dia (isterinya) termasuk orangorang yang tertinggal." 
menerima harta pusaka dan berapa kadar bahagiannya. ${ }^{54}$ Oleh yang demikian, apabila seseorang meninggal dunia, maka secara automatik harta pewaris menjadi hak ahli warisnya tanpa memerlukan kerelaan daripada pemilik harta tersebut. Begitu juga kepada sesiapa sahaja yang berhak menerima harta pusaka. Ketika terdapat ahli waris yang sepatutnya berhak menerima harta pusaka tetapi dalam realitinya tidak menerimanya disebabkan terdapat halangan, maka ketetapan ini perlu diterima oleh semua pihak. Ketetapan ini adalah hukum Allah SWT yang wajib dipatuhi oleh semua umat Islam.

Seterusnya, permasalahan wasiat wajibah itu sendiri masih menjadi kontroversi dalam kalangan ulama, iaitu terdapat sebahagian ulama membolehkan amalan wasiat wajibah dan sebahagian lagi tidak membolehkan. Keputusan penghakiman dalam kes ini walaupun berlandaskan undangundang, namun tidak menutup kemungkinan bahawa ia turut bersandarkan kepada pendapat golongan ulama yang bersetuju dengan wasiat wajibah. Mereka berpandangan bahawa ayat wasiat yang terdapat dalam Surah alBaqarah ayat 180 masih tetap hukumnya, iaitu kewajipan berwasiat. Namun demikian, hukum tersebut dikhaskan (takhșiș) dan hanya diperuntukkan bagi ahli waris yang tidak menerima harta pusaka seperti ibu bapa yang berbeza agama. Manakala bagi ibu bapa yang berhak menerima harta waris, mereka dikecualikan daripada hukum kewajipan wasiat ini dan berlaku ayat-ayat mawārith. Hal ini selari dengan pandangan Imam Aḥmad bin Hanbal, Ibn Jarir, Ibn Hazm, dan sebahagian mazhab Shāfi ${ }^{\prime}{ }^{55}$ Selain daripada itu, Ibn Hazm berpendapat bahawa apabila seseorang Muslim meninggal dan tidak berwasiat kepada keluarga yang terhalang untuk menerima harta waris, maka hakim mesti bertindak memberikan sebahagian daripada harta pusaka kepada mereka sebagai suatu wasiat yang bersifat wajib. ${ }^{56}$

Walau bagaimanapun, penulis lebih bersetuju dengan pandangan jumhur ulama yang menyatakan bahawa wasiat wajibah tidak dibolehkan oleh kerana kewajipan dalam ayat wasiat sudah dibatalkan (mansukh) dengan ayat-ayat mawārith sehingga tiada lagi kewajipan berwasiat. Lebih-lebih lagi dalam ayat wasiat diwajibkan berwasiat kepada ibu bapa dan saudara mara, sementara ayat-ayat mawārith pun sudah menetapkan bahagian masing-masing ibu bapa dan saudara mara. Alasan ini diperkukuhkan pula oleh hadis Rasulullah SAW sepertimana berikut:

54 Muhammad Yūsuf Musa, al-Mīrath fì al-Sharī'ah al-Islāmiyyah (Qāhirah: Maktabah al-Risālah, 1997), 438. Amir Syarifuddin, Hukum Kewarisan Islam (Jakarta: Kencana, 2004), 17.

55 Muhammad Hasbi Ash-Shiddieqy, Fiqih Mawaris, 275.

56 Muhammad Hasbi Ash-Shiddieqy, Fiqih Mawaris, 275. 


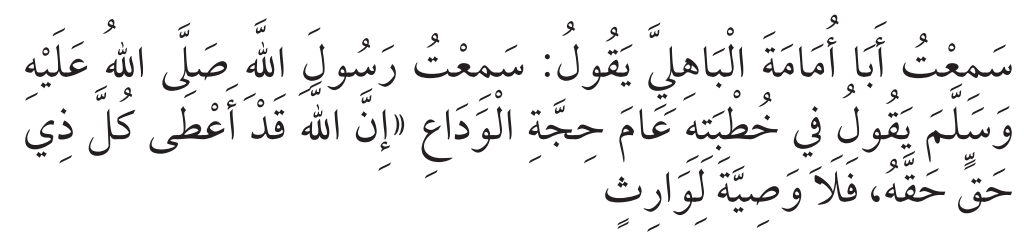

"dari Abu Umamah RA berkata: saya mendengar Rasulullah SAW bersabda dalam salah satu khutbah beliau pada tahun haji wada' bahawa Allah SWT telah memberikan hak kepada siapa yang berhak. Oleh itu, tidak ada hak mendapat wasiat bagi para ahli waris." 57

Di samping itu, berdasarkan sejarah Islam, begitu jarang sahabat Rasulullah SAW yang mengamalkan wasiat sebegini ${ }^{58}$ melainkan bagi sahabat-sahabat yang memiliki harta (khayran) yang banyak. ${ }^{59}$ Dengan demikian, jumhur berpendapat bahawa wasiat tidak lagi diwajibkan. Bahkan apabila terdapat seseorang Muslim yang berwasiat untuk ahli warisnya, maka secara hukum dianggap tidak sah atau terbatal. ${ }^{60}$

Tambahan pula, jika kita melihat kepada pelaksanaan wasiat wajibah, salah satu syarat pemberian wasiat adalah adanya kehendak dan kerelaan daripada pewasiat dan diketahui oleh orang yang berwasiat. Manakala dalam pelaksanaan wasiat wajibah boleh diperintahkan oleh hakim secara paksa dan persetujuan daripada pewasiat (orang yang meninggal). Oleh yang demikian, penulis lebih bersetuju untuk tidak memberikan wasiat wajibah kepada ahli waris yang berbeza agama.

Manakala analisis sandaran maqāṣid al-sharī'ah dalam rangka hifẓ al-nasl yang dijadikan metode oleh hakim terhadap keputusan untuk memberikan wasiat wajibah kepada ahli waris bukan Muslim agar ahli waris yang terhalang

57 Hadis riwayat Ibn Majah dalam kitab "wasāya à bab "lā wasiyyata liwārith" (905/2) no. 2713, Al-Imam Al-Hāfiz ‘Abd Allāh Muhammad bin Yāzid al-Rabi‘ Ibn Mājah, Sunan Ibn Mājah (Riyāẹ: Dār al-Salām, 1999). Tirmidhī dalam kitab "al-zakāh", bab " $f i$ nafaqah al-mar'ati min baiti zaujiha $\bar{a}$ " (48/3) no. 670, Muhammad bin Isa bin Surah al-Tirmidhī, al-Jamī' al-Ṣahīh Sunan al-Tirmidhī (Qāhirah: Muṣtafa alBābi al-Halabi, 1977). Abū Dāwud dalam kitab "al-Wāsāyā", bab 'mā ja'a fi alwasāyā li al-wārith" (114/3) no. 2870, Imam Abū Dāwud al-Sijistān̄̄, Sunan Abū Dāwud (Bayrūt: Maktab al-Dirāsat wa al-buhūth fi Dār al-Fikr, t.t).

58 Fatchurrahman, Imu Waris, 54. Al-Yasa Abū Bakar, 'Ahli Waris Sepertalian Darah: Kajian Perbandingan Terhadap Penalaran Hazairin dan Penalaran Fikih Madzhab,' 382.

59 Aḥmad Mustafa al-Maraghi, Tafsir al-Maraghi, vol. 4 (Qāhirah: al-Bab al-Halabi, 1974), 80. Rasyid Ridha, Tafsir, 132.

60 Khairani, Wasiat Wajibah dalam Pemikiran Hukum Ibn Hazm, 4. 
secara washfi tersebut terhindar daripada kemiskinan adalah mengelirukan. Ini disebabkan dalam menetapkan maqāșid itu bukanlah hanya bersifat rasional, melainkan berdasarkan kepada kriteria yang perlu dipenuhi. Imam Malik dalam al-i 'tiṣām menetapkan, sesuatu itu boleh dikategorikan sebagai bahagian daripada maqāṣid bagi menggapai kemaslahatan perlu memenuhi beberapa syarat, iaitu: pertama, harus bersifat logik (ma'qul) dan sesuai (munasib). Kedua, memelihara yang bersifat dharuri dan menghilangkan mashaqqah serta haraj. Ketiga, mașlahah yang dituju semestinya tidak bertentangan dengan dalil qat' $i .{ }^{61}$ Al-Ghazali berpandangan bahawa mașlahah tersebut perlu ditumpukan kepada peringkat keperluan, bersifat qat'i dan juga berlaku secara umum. ${ }^{62}$ Hal ini juga disokong oleh al-Shātibīi dengan menetapkan kemaslahatan tersebut harus bersifat mutlak, tidak bersifat nisbah atau subjektif sehingga jatuh kepada hawa nafsu serta harus bersifat kulliyyah. ${ }^{63}$

Dalam pandangan penulis, maqāṣid al-sharī'ah dalam rangka hifẓ alnasl dengan memberikan wasiat wajibah kepada bukan bukan Muslim adalah bersifat relatif dan bertentangan dengan juz'iyyat kerana apa yang perlu diutamakan adalah hifz al-dīn dan ianya bersifat mutlak. Apatah lagi pemberian wasiat wajibah tersebut hanya berdasarkan pertimbangan anak sedarah, dan memiliki hubungan yang baik. Perkara tersebut tidak sepatutnya menjadi alasan untuk memberikan wasiat wajibah, kerana seharusnya nilainilai agamalah yang perlu dipelihara dan dijunjung tinggi.

Seterusnya dalam kes ini, maṣlaḥah mursalah dijadikan sebagai sandaran untuk membenarkan amalan wasiat wajibah kepada waris berbeza agama dengan alasan untuk menjaga kerukunan di antara ahli waris. Tambahan lagi dalam kes ini, tindakan anak kandung yang beragama Islam yang meminta agar saudara Kristiannya turut diberikan wasiat wajibah adalah bertentangan dengan prinsip-prinsip mașlaḥah itu sendiri. Sememangnya maṣlaḥah mursalah merupakan kemaslahatan yang tidak disokong oleh dalil secara khusus, tetapi harus bersesuaian dengan tujuan syarak yang diambil dari hujah dalil. ${ }^{64}$ Sementara wasiat wajibah kepada bukan Muslim adalah bertentangan dengan tujuan syarak, bahkan ia tergolong dalam kategori mașlahah yang dibatalkan (mulgha). Hal ini kerana, hubungan kekeluargaan dikira terputus

${ }_{61}$ Al-Shāṭibī, al-I'tiṣam (Qāhirah: Maktabah Tijariyah al-Kubra, t.t.), 364-367.

62 Al-Ghazālī, al-Mustașfa fì 'Ilm al-Ușūl, vol. 2 (Bayrūt: Dār al-Kutub al-'Ilmiyah, 1983), 253-256.

63 Al-Shātịīī, al-Muwāfaqāt fì Ușūl al-Sharī‘ah, vol. 1 (Qāhirah: Maktabah alTijāriyah, t.t.), 198.

64 Al-Shātịī̄, al-Muwāeaqāat fì Ușūl al-Sharī'ah, vol. 1, 39. 
menurut syarak sekiranya berbeza agama, sekalipun mereka adalah darah daging yang sama.

Sekiranya hakim menggolongkan amalan wasiat wajibah ini kepada perkara khilaf dengan berpandukan kepada kaedah fiqh إذا حكم الحاكم في مسائل الخلاف يرفغ الخلاف. maka kaedah tersebut berlaku pada bidang muamalat sahaja. Sedangkan dalam hal perwarisan, amalan wasiat wajibah merupakan perkara yang bersifat qat'i apabila dilihat daripada ayat-ayat mawārith yang menunjukkan bahagian yang sudah ditentukan (furūd al-muqaddarah), sehinggakan ayat tersebut tidak memberikan ruang pentafsiran dengan lebih lanjut. ${ }^{65}$ Lebih-lebih lagi asas ijbari yang merupakan asas peralihan harta dari pewaris merangkumi berbagai aspek, iaitu aspek peralihan harta, aspek jumlah harta yang beralih, dan kepada siapa harta itu berhak beralih. ${ }^{66}$ Sekalipun alThufi membolehkan mașlahah mentakhsiskan al-Quran dan sunnah serta ijma ', namun demikian, hal tersebut terhad kepada bidang muamalat sahaja. ${ }^{67}$

Seterusnya metode penghakiman yang diguna pakai oleh hakim dalam pemberian wasiat wajibah dalam kes ini adalah bersandarkan kepada qiyās, iaitu mengqiyāskan pemberian harta pusaka kepada bukan Muslim melalui wasiat wajibah sebagaimana zakat diberikan kepada bukan Muslim dalam rangka qulūb ta'līf dengan harapan keluarga yang bukan Muslim akan lembut hatinya untuk menerima Islam. ${ }^{68}$ Qiyās sedemikian merupakan qiyās ma'al fariq, lebih lebih lagi wasiat wajibah yang dimaksudkan oleh hakim merupakan hukum yang berdasarkan akal, sementara syarat daripada hukum $m \bar{a} q i$ s 'alayh adalah hukum syarak bukan hukum yang berlandaskan kepada akal. Di samping itu, syarat dalam qiyās adalah hukum yang ditetapkan pada far'u masih terdapat pada aṣl, sementara wasiat yang ada pada surah alBaqarah ayat 180 merupakan hukum yang telah dinasakhkan. ${ }^{69}$

Sebagaimana disampaikan oleh hakim Muzni Ilyas bahawa illah yang terkandung dalam pemberian pusaka kepada ahli waris Muslim adalah untuk kelangsungan hidup, menjaga keturunan dan lain-lain. 'Illah yang sama pula didapati pada pemberian wasiat wajibah bagi bukan Muslim dan sekiranya

65 Idris Djakfar \& Taufik Yahya, Kompilasi Hukum Kewarisan Islam (Jakarta: PT. Dunia Pustaka Jaya, 1995), 37.

66 Amir Syarifuddin, Hukum Kewarisan Islam, 18-19

${ }_{67}$ Abdullah M. Husein Al amiri, Dekontruksi Sumber Hukum Islam Pemikiran Hukum Naj Ad Din al Thufi (Jakarta: Gaya Media Pratama, 2004), 6.

68 Ahmad Husni (Hakim, Mahkamah Agama Jombang), dalam temu bual beliau dengan penulis pada 2 Mac 2017; Suyatman (Hakim, Mahkamah Agama Jombang), dalam temu bual beliau dengan penulis pada 2 Mac 2017.

69 Nashroen Harun, Ushul Fiqh 1 (Jakarta: Logos Wacana Ilmu, 1997), 75. 
berubah 'illah, maka akan berubah juga hukumnya. ${ }^{70}$ Namun demikian, menurut penulis, 'illah yang dimaksudkan oleh hakim Muzni tersebut bertentangan dengan kriteria 'illah yang sebenar, kerana terdapat beberapa kriteria untuk menggolongkan sesuatu sebagai 'illah. Iaitu 'illah harus jelas dan dapat dilihat oleh salah satu lima deria, 'illah merupakan sifat yang sudah pasti dan memungkinkan untuk diterapkan pada far' $u$, 'illah harus sesuai dengan hikmah hukum, 'illah harus terdapat pada aṣl dan far' $u$ dan ketiadaan nas yang menyatakan sifat tersebut tidak dipandang sebagai 'illah. Walau bagaimanapun, pemberian wasiat wajibah bagi bukan Muslim bertentangan dengan kriteria tersebut.

Metode lain yang digunakan oleh hakim menurut Hakim Tinggi Rum Nessa dan Hakim Zamroni adalah tafsiran sistematik, di mana hakim menggabungkan pentafsiran perundangan dalam KHI dengan perundangan lain (undangundang sivil) sehingga boleh menentukan hukum yang memberikan keadilan dan kebenaran kepada masyarakat. ${ }^{71}$ Penggunaan metode ini sememangnya perkara yang dibenarkan, namun demikian dalam hal pertikaian permasalahan agama, sepatutnya seseorang hakim membuat perbandingan antara hukum Islam itu sendiri.

Manakala menurut Hakim Tinggi Hasan Bisri, dalam kes ini hakim menggunakan metode tafsiran teleologi di mana kedudukan hakim yang menetapkan makna dalam undang-undang atas dasar kemasyarakatan sehingga akhirnya hakim memutuskan perkara sesuai dengan tujuan yang ingin dicapai dalam undang-undang meskipun tidak menggunakan undangundang sebagai rujukan penghakiman kerana dianggap kurang layak bahkan sudah usang. ${ }^{72}$ Ditambah pula oleh Hakim Tinggi Muzni Ilyas, bahawa hakim juga menggunakan metode tafsiran sejarah. Penggunaan metode ini dilihat daripada penyelidikan terhadap sejarah undang-undang, di mana KHI memberikan hak waris melalui wasiat wajibah kepada yang bukan waris adalah bagi mewujudkan keadilan dan kemaslahatan bagi masyarakat. ${ }^{73}$ Sebenarnya penggunaan metode tersebut tidak bercanggah dengan syarak demi

\footnotetext{
70 Kaedah fiqh, "apabila 'illah berubah, maka hukum pun ikut berubah."

71 Muhammad Rum Nessa (Hakim Tinggi, Mahkamah Tinggi Agama Jawa Timur), dalam temu bual beliau dengan penulis pada 6 Mac 2017; Zamroni (Hakim Agama, Mahkamah Agama Sumenep), dalam temu bual beliau dengan penulis pada 23 Januari 2017.

72 Hasan Bisri (Hakim Tinggi, Mahkamah Tinggi Agama Jawa Timur), dalam temu bual beliau dengan penulis pada 3 Mac 2017.

73 Muzni Ilyas (Hakim Tinggi, Agama Mahkamah Tinggi Jawa Timur), dalam temu bual beliau dengan penulis pada 3 Mac 2017.
} 
kemaslahatan, tetapi mașlahah yang ingin dicapai dalam pemberian wasiat wajibah bagi bukan Muslim adalah bertentangan dengan nas. Sementara jumhur ulama mengatakan bahawa jika terdapat pertentangan antara nas dan mașlahah, maka sandaran nas lebih diutamakan. ${ }^{74}$

Seterusnya, penggunaan metode tafsiran secara meluas sebagaimana yang dinyatakan oleh Hakim Tinggi Agus Dimyati, iaitu ketika hakim mentafsirkan undang-undang yang terdapat dalam KHI yang menentukan wasiat wajibah hanya terhad kepada anak angkat atau ibu bapa angkat sahaja seterusnya meluas menjadi pentafsiran kepada wasiat wajibah bagi bukan Muslim. ${ }^{75}$ Namun, penulis berpandangan bahawa perluasan makna tersebut tidak bersesuaian dengan hukum syarak, terutamanya berkaitan dengan tempat berpijaknya hakim dalam melakukan perluasan makna. Ini disebabkan pada dasarnya wasiat wajibah bagi anak angkat adalah merupakan amalan yang tiada sandaran dalil yang menyokongnya, sementara ayat-ayat mawārith yang merupakan dalil qat'i yang harus dijunjung tinggi.

Selain daripada itu, Hakim Dimyati juga menambah bahawa hakim juga menggunakan metode argumentum a per analogium yang secara jelas dapat dilihat apabila hakim menyamakan aturan perundangan kepada perkara yang serupa atau sejenis, iaitu kelayakan waris bukan Muslim menerima harta pusaka melalui wasiat wajibah. Di sini hakim menggunakan analogi tersebut dengan kes wasiat wajibah bagi anak angkat. ${ }^{76}$ Ini merupakan penyamaan yang tidak bersesuaian dengan prinsip qiyās disebabkan sepatutnya penyamaan hukum tersebut pada hukum syarak, tidak keluar daripada kaedah qiyās serta yang disamakan tidak boleh bertentangan dengan nas ataupun ijm $\bar{a}{ }^{‘} \cdot{ }^{77}$

Menyingkapi kes ini, penulis memberikan cadangan agar tashāwur al-qismah diberikan kepada ahli waris, iaitu pembahagian yang sudah dibincangkan, terutama kepada ahli waris yang tidak menerima bahagian harta pusaka disebabkan oleh sebab-sebab tertentu. Cadangan ini selari dengan firman Allah SWT di dalam al-Quran:

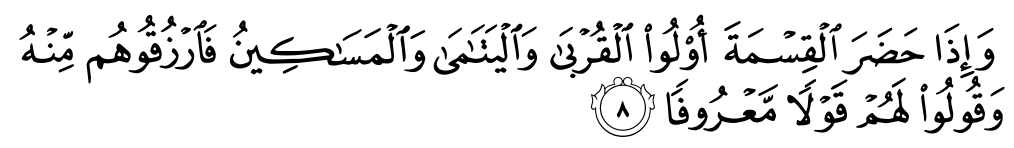

\footnotetext{
74 Abdullah M. Husein Al amiri, Dekontruksi Sumber Hukum Islam Pemikiran, 4-7.

75 Agus Dimyati (Hakim Tinggi, Mahkamah Tinggi Agama Jawa Timur), dalam temu bual beliau dengan penulis pada 3 Mac 2017.

76 Agus Dimyati (Hakim Tinggi, Mahkamah Tinggi Agama Jawa Timur), dalam temu bual beliau dengan penulis pada 3 Mac 2017.

77 Nashroen Harun, Ushul Fiqh, 75.
} 
"Dan apabila sewaktu pembahagian itu hadir kerabat, anak yatim dan orang miskin, maka berilah mereka dari harta itu (sekurang-kurangnya) dan ucapkanlah kepada mereka perkataan yang baik..."

(Surah al-Nisā', 4: 8)

Ayat ini memberikan pengertian bahawa ketika keluarga yang ditinggal mati oleh salah satu ahlinya berbincang mengenai pembahagian harta waris, maka apabila ahli keluarga lain yang tidak menerima bahagian mereka, sepatutnya pihak-pihak yang menjadi ahli waris memberikan bahagian sekadar kepada mereka. Namun demikian, apabila terdapat ahli waris yang tidak bersetuju memberikan sedikit bahagian kepada ahli waris yang tidak berhak menerima harta waris, maka tashāwur al-qismah tidak dapat diberikan. Di sini, tashāwur al-qismah berbeza dengan wasiat wajibah yang pelaksanaan harus dilakukan secara paksa tanpa mempertimbangkan kehendak yang meninggal dan ahli waris lainnya. Namun dalam konsep tashāwur al-qismah sifatnya tidak dipaksa, melainkan mengharapkan keikhlasan hati daripada ahli-ahli waris untuk mengurangkan sedikit bahagian yang diperoleh diberikan kepada ahli waris yang tidak berhak, dan had bahagiannya dibincangkan bersama.

\section{KESIMPULAN}

Dalam penghakiman bagi kes No.0140/Pdt.P/2012/PA.Sby, tindakan hakim memberikan harta pusaka kepada ahli waris berbeza agama melalui wasiat wajibah menunjukkan bahawa Islam adalah agama rahmatan lil 'alamiin yang dapat dinikmati oleh seluruh masyarakat tanpa mengira pegangan agama. Namun demikian, penulis menolak wasiat wajibah kepada ahli waris yang berbeza agama kerana keputusan tersebut bercanggah dengan hukum syarak disebabkan menyalahi aturan al-Quran surah al-Nisā' ayat 14 tentang ketaatan terhadap ketetapan Allah SWT. Alasannya adalah sebagaimana apa yang telah diwahyukan di dalam al-Quran, maka hubungan pewaris dengan ahli waris meskipun sedarah, terputus kerana berbezanya agama. Demikian juga prinsip keadilan dalam Islam merupakan keadilan berimbang, dan dalam perkara ini ketegasan untuk menjaga agama sangat asas dalam darūriyyah al-khamsah. Di samping itu, asas perwarisan Islam yang mengamalkan asas ijbari tidak memberi pilihan sama ada suka mahupun tidak suka bagi kedua-dua pihak, serta keberadaan ayat wasiat sudah ternasakhkan dengan ayat waris dan yang terakhir tidak dijumpai amalan para sahabat yang memberikan wasiat bagi keluarga yang berbeza agama. 
Metode yang digunakan oleh hakim adalah berpegang kepada maqāșid al-sharī'ah dalam rangka hifž al-nasl berbeza dengan ketentuan maqāșid itu sendiri. Demikian juga amalan pemberian zakat kepada bukan Muslim juga bertentangan dengan prinsip qiyās. Manakala metode tafsiran sistematik, tafsiran teleologi, tafsiran secara meluas serta metode argumentum a per analogium hakim lebih berpijak dengan metode yang terdapat pada undangundang konvensional yang tidak boleh diamalkan pada hukum Islam.

\section{RUJUKAN}

Abdul Aziz Dahlan (ed.), Ensiklopedia Hukum Islam, vol. 1 (Jakarta: PT. Ichtiar Baru van Hoeve, 1996).

Abdul Manan, 'Beberapa masalah hukum tentang wasiat dan permasalahannya dalam konteks kewenangan peradilan agama,' Mimbar Hukum Aktualisasi Hukum Islam, 38/1 (1998): 20-32.

Abdullah M. Husein Al amiri, Dekontruksi Sumber Hukum Islam Pemikiran Hukum Naj Ad Din al Thufi (Jakarta: Gaya Media Pratama, 2004).

Aḥmad Mustafa al-Maraghi, Tafsir al-Maraghi, vol. 4 (Qāhirah: al-Bab alHalabi, 1974).

Amir Syarifuddin, Hukum Kewarisan Islam (Jakarta: Kencana, 2004).

Badran Abū al-Ainani, Aḥkām al-Wașaya wa al-Awqaf (Iskandariyah: Muassasah Shabab al-Jami'ah, 1982).

Chua Yan Piaw, Kaedah dan Statistik Pengkajian: Asas Statistik Pengkajian Buku 2 (Malaysia: McGraw-Hill, 2006).

Fatchur Rahman, Ilmu Waris (Bandung: Al-Ma'arif, 1994).

Al-Ghazālī, al-Mustashfa fì 'Ilm al-Ușūl, vol. 2 (Bayrūt: Dār al-Kutub al'Ilmiyah, 1983).

Ibn Hazm, al-Muhalla, vol. 9 (Bayrūt: Dār al-Fikr, 1983).

Idris Djakfar \& Taufik Yahya, Kompilasi Hukum Kewarisan Islam (Jakarta: PT. Dunia Pustaka Jaya, 1995).

Imam Abū Dāwud al-Sijistān̄̄, Sunan Abū Dāwud (Bayrūt: Maktab al-Dirāsat wa al-buhūth fi Dār al-Fikr, t.t).

Al-Imam al-Hāfiz Ab̄̄ 'Abd Allāh Muḥammad bin Yāzid al-Rabi' Ibn Mājah, Sunan Ibn Mājah (Riyāụ: Dār al-Salām, 1999).

Imam Bukhārī, Șaḥịh al-Bukhārī (Qāhirah: Dār al-Ḥadīth, 1984).

Imam Muslim, Șaḥ̄ḥ Muslim (Qāhirah: Dār al-Hadīth, 1988). 
Al-Jaṣaṣ, Ahkām al-Qur'ān, vol. 2 (Bayrūt: Dār al-Kitāb al-'Arabī, t.t.).

Jasim Zahid, Asbāb al-Irth wa Mawāni'uhu fì al-Fiqh al-Islāmī (Makkah: Jāmi'ah Umm al-Qura, 1982).

Khairani, Wasiat Wajibah dalam Pemikiran Hukum Ibn Hazm (Banda Aceh: Searfiqh, 2012).

Liza Erwina, 'Penemuan hukum oleh hakim,' USU Digital Library (2002).

M. Ali Ash-Shabuni, Pembagian Waris menurut Islam (Jakarta: Gema Insani, 1995).

M. Muhyidin Abd. Hamid, Panduan Waris Empat Madzhab, terj. Wahyudi Abdurrahim (Jakarta: Pustaka Al-Kautsar, 2009).

M.Yahya Harahap, Informasi Materi KHI; Mempositifkan Abstraksi Hukm Islam (Jakarta: Yayasan al-Hikmah, 1993/1994).

Moh. Muhibbin \& Abdul Wahid, Hukum Kewarisan Islam; Sebagai Pembaruan Hukum Positif di Indonesia (Jakarta: Sinar Grafika, 2009).

Muhammad Abū Zahrah, Sharḥ Qānūn al-Wașiyyah (Qāhirah: Maktabah alMașriyah, 1983).

Muhạmmad bin Aḥmad al-Qurțubī, al-Jami' li Ahkām al-Qur’ān, vol. 3 (Qāhirah: Dār al-Ḥadīth, 1999).

Muhammad bin Isa bin Surah al-Tirmidhī, al-Jamī’al-Saḥ̄h Sunan al-Tirmidhī (Qāhirah: Muștafa al-Bābi al-Halabi, 1977).

Muhammad Hasbi Ash-Shiddieqy, Fiqih Mawaris (Semarang: PT. Pustaka Riski Putra, 1987).

Muḥammad Yūsuf Mūsā, al-Mīrath fì al-Sharī'ah al-Islāmiyyah (Qāhirah: Maktabah al-Risālah, 1997).

Nashroen Harun, Ushul Fiqh 1 (Jakarta: Logos Wacana Ilmu, 1997).

Nurdin Juddah, 'Metode Ijtihad Hakim dalam Penyelesaian Perkara,' Jurnal Diskursus Islam, 1/2 (2013): 254-264.

Rashīd Riḍā, Tafsīr al-Qur'ān al-Hakìm, vol. 2 (Qāhirah: Maktabah alQāhirah, t.t.).

Riyanta, 'Metode Penemuan Hukum: Studi Komparatif Hukum Islam dan Hukum Positif,' Jurnal Penelitian Agama, 17/2 (2008): 406-427.

Al-Shātịī, al-I'tiṣām (Qāhirah: Maktabah Tijāriyah al-Kubrā, t.t.).

Al-Shātịīi, al-Muwāfaqāt fì Ușūl al-Sharī'ah, vol. 1 (Qāhirah: Maktabah alTijāriyah, t.t.).

Sugiyono, Metode Penelitian Kombinasi (Mixed Methods) (Bandung: 
Alfabeta, 2014).

Suparman Usman \& Yusuf Somawinata, Fiqh Mawaris: Hukum kewarisan Islam (Jakarta: Gaya Media, 1997).

Titin Samsudin, 'Peranan Hakim dalam Pengeluaran hukum,' Jurnal al-Mizan, 10/1 (2014): 98-106.

Al-Yasa Abu Bakar, 'Ahli Waris Sepertalian Darah: Kajian Perbandingan Terhadap Penalaran Hazairin dan Penalaran Fikih Madzhab,' (Disertasi Sarjana, Fakultas Pasca Sarjana IAIN Sunan Kalijaga, Yogyakarta, 1989).

Yūsuf Mūsā, al-Tirkah wa al-Mīrath fì al-Islām; Bahth Muqāran (Qāhirah: Dār al-Ma'rifah, 1967).

\section{Statut}

Undang-undang No. 14 Tahun 1970.

Undang-undang No. 14 Tahun 1970.

\section{Kes}

Keputusan kes nombor $51 \mathrm{~K} / \mathrm{AG} / 1999$ bertarikh 2 Februari 1999.

\section{Temu bual}

Agus Dimyati (Hakim Tinggi, Mahkamah Tinggi Agama Jawa Timur), dalam temu bual beliau dengan penulis pada 3 Mac 2017.

Ahmad Husni (Hakim, Mahkamah Agama Jombang), dalam temu bual beliau dengan penulis pada 2 Mac 2017.

Amran Suadi (Hakim Agung, Mahkamah Agung R.I), dalam temu bual beliau dengan penulis pada 7 Mac 2017.

Eni Rianing Taro (Hakim Agama, Mahkamah Agama Mojokerto), dalam temu bual beliau dengan penulis pada 3 Mac 2017.

Hasan Bisri (Hakim Tinggi, Mahkamah Tinggi Agama Jawa Timur), dalam temu bual beliau dengan penulis pada 3 Mac 2017.

Muhammad Rum Nessa (Hakim Tinggi, Mahkamah Tinggi Agama Jawa Timur), dalam temu bual beliau dengan penulis pada 6 Mac 2017.

Mulyani (Hakim Agama, Mahkamah Agama Mojokerto), dalam temu bual beliau dengan penulis pada 3 Mac 2017.

Muzni Ilyas (Hakim Tinggi, Agama Mahkamah Tinggi Jawa Timur), dalam 
temu bual beliau dengan penulis pada 3 Mac 2017.

Suyatman (Hakim, Mahkamah Agama Jombang), dalam temu bual beliau dengan penulis pada 2 Mac 2017.

Tamali (Hakim Agama, Mahkamah Agama Mojokerto), dalam temu bual beliau dengan penulis pada 3 Mac 2017.

Zamroni (Hakim Agama, Mahkamah Agama Sumenep), dalam temu bual beliau dengan penulis pada 23 Januari 2017. 
Jurnal Syariah, Jil. 26, Bil. 2 (2018) 263-290 